\title{
4.3 Інноваційні чинники формування трудового потенціалу сучасного працівника
}

Active development of the state is possible, provided its sustainable economic growth is ensured. Therefore, today the issue of developing the potential of Ukrainian companies is quite relevant. The labor potential of a modern company is the ratio of the total number of components that reflect educational and professional characteristics of different groups of employees.

Labor potential is a set of opportunities for employees to actively or passively participate in the production process within a certain organizational structure, taking into account logistical, technological, informational and other resources, is a complex structural social-economic entity with a number of components.

A modern employee is an active participant in the production process and is often forced to work in new, unusual for him conditions, to apply new technological opportunities, which in turn require the development of non-standard skills and abilities. Such new, innovative for both the employee and the company, the functionality of the employee formed the basis of the creative potential of the company.

Creative potential is realized in creative achievements of the employee, which allows to develop as a specialist, professional, innovative person, and ensures development of the company itself. The relationship between creativity and personality has been the subject of careful study almost from the beginning of the study of creativity, but even today it is unclear whether personality traits, such as emotional intelligence and emotional creativity, are drivers for the people with disabilities to create potential for implementation of their innovative ideas.

D. Bohynia, O. Grishnova, V. Piskunova, E. Libanova, L. Shaulska and many others studied the labor potential and the factors that influence its formation and determine its effectiveness. The other side of renewal of labor potential, formation and realization of new human qualities is a manifestation of creativity and innovative thinking. Significant attention to the development of creativity of labor potential has 
been studied by such well-known scientists as: K. Biletska, O. Harun, Yaroshevska O., O. Petina et al.

K. Taylor, J. Guilford, E. Torrence, M. Volakh, N. Kogan are among the world's researchers of the category of creativity, the most famous.

A necessary condition for development of the national economy is to increase efficiency, which is largely determined by the ability of economic entities to use and generate new knowledge, acquire progressive intellectual skills, form productive systems of relations with the environment that can be interpreted as human intellectual capital. Assessment of intellectual capital is the most important tool for effective management of its quality in the interests of innovative development of socialeconomic systems.

The role of knowledge as a source of development of innovative economy is to grow and increase the importance of quality and degree of use of human capital in the process of social production, ability to create an intelligent product for high-tech industries.

Human capital is formed at different stages of the human life cycle, so it is considered one of the most complex tools of economic management. Assessing the opportunities and results of innovative development one should distinguish between the following concepts: "labor resources", "human potential", "labor potential", "human capital" and "creative potential".

O. Grishnova notes that approaching a human as a passive object of external management, which deprives employees of their own goals, needs and interests, is a distinctive feature of the concept of "labor resources" from other concepts [257, p. 9]. People are treated as objects of management, as carriers of labor or elements of labor resources, rather than a social-economic component.

The human potential of society is a reserve of physical and mental health (physical potential), training and other acquired abilities (potential acquired) labor resources that can be quickly used at the right time.

Labor potential is considered as an integrated assessment of quantitative and qualitative characteristics of the economically active population [258, p. 42]. Labor 
potential is becoming the most common category, as the basis of all production was man. This was due to a number of economic, demographic, social and scientific factors. Human capital is seen as an economic category that is very close to real, physical capital. Human capital is recognized by the world as the most valuable resource, much more important than natural resources or accumulated wealth.

The creative potential of an individual is a set of intellectual and creative abilities of a person, which are used by him in his activity.

Education is a key factor in improving human capital in sustainable development. Improving the human resources learning management system can help improve the quality of the workforce and accelerate economic development.

The effectiveness of all types of capital, including intellectual, creative, depends on the level of development of organizational and entrepreneurial capital.

In 2015, American scientists R. Florida, S. Mellender and K. King proposed the Global Creativity Index (GCI), which allows you to assess the country's creativity at the macro level on indicators such as talent, technology and tolerance [260].

In 2015, Ukraine ranked 45th among 139 countries in the global creativity index. But since then, this index has never been calculated due to the complexity of the methodology.

There is also the Global Innovation Index (GII), which includes an indicator of creative outputs. This indicator is determined by the following components: valuation of intangible assets; determining the number of innovative goods and services; level of Internet creativity, education, etc.

In 2020, Ukraine ranked 45th in the overall ranking of the Global Innovation Index 2020 and scored 37.4 points out of 100 . If we consider some components of this index, Ukraine ranked 23rd with regard to innovations in education (+20 steps), 23rd with regard to knowledge creation (patents and inventions) (-6 steps), and 1st with regard to registration of utility models. [261].

This gives grounds to claim that Ukraine's creative potential is strong enough for innovative economic development, but the use of this potential is incomplete. 
Analyzing economic processes and prospects for the development of the national economy, it is important not only to understand the availability of innovative, creative potential, but also to be able to assess it using quantitative and qualitative methods.

One of the most interesting in terms of breadth of research is the approach to the assessment of creative potential was proposed by D. Krykunenko [262]. It is confined to using a three-dimensional vector model of interpreting the creativity of the company's staff, which reflects the actual level and potential for creativity. D. Krykunenko's three-dimensional vector model is quite complex for practical application, as it uses the values of the components of intellectual and creative resources of staff, which are calculated on the basis of expert evaluation, and they are known to be quite subjective.

There is another model for assessing creative potential (authors Yaroshevskaya O.V., Krasnostup V.N.). This model contains a complex set of indicators for assessing the creative potential of the internal and external environment [254]. The use of such indicators will reveal the hidden opportunities for innovative development of personnel in any industry.

The main indicators included in this system are the share of the population with higher education in the total population; the number of free economic zones of the relevant profile; the share of economically active population in the total population; the share of labor migration abroad; the share of the population with higher education in the total number of emigrants; turnover of highly qualified personnel; the share of employees with higher education in the total number of staff; staff training costs; indicator of inventive activity by quantity; R\&D costs, etc.

These indicators allow a comprehensive assessment of the cost of research and development of creative potential of all stakeholders and predict the development of creativity in the industry. The use of the above elements of human capital, in turn, allows the business entity to gain a competitive advantage, improve profitability, create or increase its market share.

The formation of the creative potential of human capital begins at the level of preschool education and is directed towards the system of higher education. 
Education is becoming important in the development of the creative component of labor potential today. The educational component supports the professional development of the employee and encourages him/her to continuous self-improvement.

In most countries, universities are a major component not only of the education system but also of the national innovation system. However, now that the knowledge economy is emerging, the provision of full lifelong learning for all who want and are able to provide individualization of educational programs in demand in the labor market is the right of everyone who understands the impact of educational institutions on innovative economic development.

The concept of creative potential of a participant in the production process is an integrated quality, which by its properties reveals the ability of man to generate original, innovative, modern ideas to solve various production problems and their easier perception. Also, it should be noted that the creative potential of the participant of the work process reflects the degree of his ability to creative self-realization in professional activities.

The processes of forming the creative potential of participants in the educational process intensified during the development of online education under the influence of the global pandemic. Online education can be defined as "a way to solve the problem of unequal access to educational resources through the use of modern electronic learning tools" [263, p. 41]. The availability of online training provides continuity and diversity of educational and cognitive opportunities for professional and personal development of employees in any field. Thus, it is necessary to highlight the basic principles of developing the creative potential of participants in the production process:

The principle of continuity of self-learning. Today you should develop your knowledge and skills on a regular basis, and not stop the process.

The principle of digitalization of the educational process. It is the development of digital skills that will help participants in the production process to develop their own creative abilities. 
The principle of flexibility and adaptability. You should be ready to leave outdated methods of work and master modern intelligent systems of production and management.

The principle of goal setting. Every employee must set goals of selfimprovement and development not only to meet the requirements of production of goods and services, but also for personal growth.

Today, it is important to pay special attention to educators, as they are involved in the learning process as service providers, and at the same time, they require continuous self-study. This multifunctional nature and importance of education is determined by the specifics of its services, which, first of all, should include the formative and developing levels of knowledge, skills, moral qualities, etc. to achieve comfortable living conditions and management that connect man, production and state [256].

International educational and labor migration is a special threat to the sustainable development of Ukrainian companies, as the formation of highly qualified personnel, accumulation of intellectual capital of the company is one of the important factors of its progressive development and positive changes in the economic system.

International educational migration is the constant movement of people to obtain a certain level of education. It includes the geographical movement of pupils, students, graduate students, doctoral students, and already established professionals who, under the pretext of international educational migration, improve their skills in various educational institutions and companies abroad.

Analysis of the number of applicants for higher education abroad has shown a growing trend over the past decade. If in 2011 the number of Ukrainian students abroad amounted to 37.6 thousand persons, in 2018 it was already 78 thousand persons [264].

The main recipient countries of higher education include Poland, Austria, Slovakia, the Czech Republic, Germany, Spain, Canada and Italy.

The most important factor that motivates Ukrainian students to receive higher education abroad is the potential to receive higher wages, working conditions and 
permanent residence after graduation, which confirms the direct negative impact on the labor potential of Ukrainian companies.

According to a survey conducted online in 2018 by the CEDOS analytical Center, among more than 1,000 Ukrainians studying in Poland, only 6\% intended to return to Ukraine after graduation [265]. There are even fewer people from other countries who want to return to Ukraine. Most plan to work in more developed countries.

During 2019-2021, due to the COVID-19 pandemic, the number of students going abroad decreased, but it is only a matter of time.

A specific feature of educational migration, according to researchers, is its least harmful nature in contrast to other types of migration. The desirability of educational migration is determined by income not only for the education sector (or individual free economic zones), but also for the economy of the country (region) that provides educational services in general. In addition, consumers of educational services are a potential workforce of appropriate qualifications [266].

International labor migration is a component of the world economic system, it is the result of the evolution of labor, the system of international division of labor and integration. The natural and necessary phenomenon of the coexistence of different peoples, international relations, ethnic and social groups and countries is called labor migration. The movement of large masses of people has happened and always happens. The reasons for relocation are divided into economic and non-economic. Economic reasons are related to different levels of social-economic development and lead to labor migration to high-standard countries from less developed countries. Economic migration also depends on the functioning of TNCs, joint ventures, the growth of capital migration and the presence of structural unemployment. Non-economic factors include: political, military, religious, national, cultural, family and other social factors [265].

The main reasons for the international migration of labor can also include globalization, the movement of foreign direct investment, the development of transport and communications, the official policy of migration regulation. An important 
component of the development of migration processes is the activities of transnational and multinational corporations, which actively involve employees from less developed countries.

Ukraine is considered one of the largest labor donor countries in Europe. Ukrainian citizens work both in Western European countries and in EU member states, in the CIS, and even overseas. The main reasons for leaving the economically active population of Ukraine are the long political crisis, dissatisfaction with the economic situation, failure to provide conditions for the realization of the opportunities of its citizens, much higher wages in immigration countries, events in eastern Ukraine. Faced with obstacles in finding the necessary conditions for employment in their home country, young, active, settled people are looking for them abroad. Along with the outflow of labor there is an outflow of creative, intellectual potential of the state.

In the last decades of the twentieth century. international labor migration has become one of the components of the process of globalization of the world economy. On the one hand, global change is now accompanied by an intensification of international migration processes, on the other hand, it is recognized that people have less mobility than money, goods or ideas.

The globalization of higher education is accelerating modern world migration. The lion's share of higher education students abroad are trying to stay and work in industrialized countries. At the same time, the processes of labor migration of specialists to work in less developed countries are quite common, while in the homeland graduates of Western universities cannot find work. Today, Ukraine is a powerful donor of creative workforce, full of innovations, ideas and endowed with energy to implement such ideas. The formation of appropriate economic policies aimed at preventing the outflow of educational and labor resources would ensure not only increasing the supply of quality and highly skilled labor, but also preserving the creative potential of our country's labor resources.

Thus, the development of the creative component of the labor potential of the participants in the production process in modern conditions involves primarily the creative nature of their activities. Both international and Ukrainian experience in the 
development and use of creative characteristics of employees shows that the development of the individual, his talents and abilities is a reliable investment in the future of the state and the labor potential of the individual. The introduction of creative skills and creative approaches to the development of workers in any industry is the basis for easy adaptation to new requirements in the COVID-19 pandemic and will reduce the outflow of educated professionals to study and work abroad. 